\title{
An Analysis of the Role of Pension Funds Adjudicator in South Africa
}

\author{
Lufuno Nevondwe \\ Kola O. Odeku \\ Faculty of Management and Law, School of Law, \\ University of Limpopo, South Africa \\ E-mail: lufuno3@gmail.com
}

\section{Doi:10.5901/mjss.2013.v4n13p817}

\begin{abstract}
This article examines the adjudication of complaints at the Office of the Pension Funds Adjudicator. The article looks at the appointment, powers and functions of the Adjudicator. Members are often not aware of what constitutes a complaint in terms of the Act and accordingly refer frivolous complaints to the Office of the Pension Funds Adjudicator causing unnecessary backlog. The article argued that the insertion of chapter VA has been successful in disposing complaints in procedurally fair, economical and expeditious manners. There are however, disputes that appear to fall within the jurisdiction of the Pension Funds Adjudicator and the Commission, Mediation and Arbitration, in order to evade confusion, this article shall determine which matters are out of the Jurisdiction of the Pension Funds Adjudicator so that members can lodge complaints with the appropriate and relevant forum. The article highlights the time-barring provisions and the implications thereof on the resolution of complaints in terms of the Act.
\end{abstract}

Keywords: Pension, Adjudicator, Adjudication, complaints, Time limits, legal representation.

\section{Introduction}

Until recently, the Office of the Pension Funds Adjudicator (OPFA) in South Africa was known for delay in processing complaints. Many complainants had lost confidence in the OPFA simply because the complaints would take months to be finalised. This was indeed against the sole purpose for which the OPFA was established, which is to deal with matters expeditiously. Perhaps one may submit that the delay in processing complaints is justifiable considering the fact that the Pension fund industry is one of the largest industries in South Africa that contributes significantly to the growth of the country's economy (Stipanowich, 2004). Similar to other industries, the Pension fund industry is also subject to its fair amount of challenges relating to maladministration and abuse of power within the industry. Disputes of fact or law that often arise as well as complaints of the employer's dereliction of duty in connection with pension funds are common.

In terms of section 1 of the Pension Funds Act 24 of 1956, a "complaint 'means a grievances of a complainant relating to the administration of a fund, the investment of its funds or the interpretation and application of its rules, and alleging-

a. that a decision of the fund or any person purportedly taken in terms of the rules was in excess of the powers of that fund or person, or an improper exercise of its powers;

b. that the complainant has sustained or may sustain prejudice in consequence of the maladministration of the fund by the fund or any person, whether by act or omission;

c. that a dispute of fact or law has arisen in relation to a fund between the fund or any person and the complainant; or

d. that an employer who participates in a fund has not fulfilled its duties in terms of the rules of the fund.

Section 1 also defines complainant as any person who is a member or former member of a fund; a beneficiary or former beneficiary of a fund; an employer who participates in a fund; a board of management of a fund or member of the board or any person who has an interest in a complaint."

It is against the backdrop of the various complaints that a body to investigate and make determination of the complaints of any fraud becomes very essential.

The Pension Funds Act 24 of 1956 (Act) in South Africa was amended in 1996 to create a special process by which complaints against pension funds can be investigated and decided on (Merwe, 2004). A new chapter VA was enacted creating the Office of the Pension Funds Adjudicator (OPFA) with the object of disposing complaints in a 
procedurally fair, economical and expeditious manner (Murphy, 2001). The establishment of the OPFA is a significant phenomenon in promoting the rights of everyone to have their disputes resolved by an independent, impartial tribunal and forum in line with section 34 of the South African constitution, Act 108 of 1996.

Accordingly, if a person is aggrieved by the decision of the trustees or is not satisfied with the calculation of his or her benefits, he or she is entitled to lodge a complaint with the OPFA in terms of chapter $V$ of the Act. This however was not feasible prior to the establishment of the OPFA in April 1996 as there was no tribunal that investigated, conciliated and adjudicated complaints lodged in terms of the Act.

In its current form, the OPFA utilizes different processes to resolve disputes in an expeditious and economical manner and this includes the New Complaints Unit (NCU), conciliations and adjudication (PFA, 2011/12). The purposes of this article will be on the adjudication of pension funds complaints and the determination of whether this process has really contributed to resolving disputes expeditiously or not.

\section{What is Adjudication in the Context of the OPFA?}

Adjudication generally refers to processes of decision making that involve a neutral third party with the authority to determine a binding resolution through some form of judgment or award (Lew and Mistelis, 2003). Specifically, adjudication refers to litigation or court-based resolution of conflicts (Colby, 1998). It is usually as a result of situations when the parties involved in a dispute are adamant and have the conviction that through adjudication, they will get redress (Fraser, 2001). In the words of Kwakwala (2010:3) "adjudication is an adversarial process that in many cases degenerates into a battlefield, where questions of expense, delay, compromise and fairness have low priority". For the purpose of this paper, adjudication refers to the process by which the adjudicator settles complaint that is lodged by the complainant and makes a determination which is binding on both the complainant and the respondent. In the case of Sligo v Shell Southern Africa Pension Fund \& Another, the court observed:

"The complaints adjudication process established by Chapter $V$ of the Act constitutes a unique and special process granting complainants extensive statutory rights in relation to their pension benefits. It is an interventionist instrument of policy enacted in the interests of greater social security.... The aim of the complaints adjudication process is to provide a mechanism of enhanced protection of [pension benefits]. To accomplish this end the Adjudicator is given extensive investigative powers which can be exercised in an inquisitorial manner.

\section{The Status of OPFA}

The Pension Funds Adjudicator is a specialist tribunal that aspires to be a respected institution, makes binding and final determinations in pension fund complaints submitted to it in terms of the Act (Adler, 2006). OPFA resolves complaints in terms of the Act in order to uphold the integrity of the pension fund industry and to protect the interests of pension fund members. In the case of Henderson v Eskom and another [1999] BPLR 353 (PFA) the adjudicator found that "the Adjudicator is a quasi-judicial organ with power to determine disputes, performs judicial acts upon consideration of facts and circumstances, imposes liability and affects the rights of other". This was also confirmed in the case of Old Mutual Life Assurance Co (South Africa) Ltd v Pension Funds Adjudicator and Others 2007 (3) SA 458 (C) at paragraph 12 where it was stated that 'The adjudicator in settling the complaints in terms of the PFA performed a judicial function.'

The court observed in the cased of Henderson v Eskom that OPFA is an administrative tribunal and not a court, albeit in many respects, OPFA and the functions of the Adjudicator resembles those of a court of law. However, unlike a court of law, the OPFA can still hear a complainant even if the latter has not set out the entire complaint in the original document, especially if the main thrust of the complaint is clear from all the documents filed in connection with the complaint read together. This position was reinforced by the court in the case of IBM South Africa Pension Fund v IBM South Africa (Pty) Ltd (2000) 21 ILJ 1467) (PFA)at Paragraph 13 where the adjudicator remarked as follows:

This forum is not a court of law. It is an office with investigative powers and can thus not be limited in its functions simply to adjudicating on disputes "as pleaded" by the parties. That would defeat the whole purpose of this office."

According to the PFA (2011/12:1), the mandate of the OPFA is to ensure procedurally fair, economical and expeditious resolution of complaints in terms of the Act, by:

"Ensuring that its services are accessible to all; investigating complaints in a procedurally fair manner; reaching a just and expeditious resolution of complaints in accordance with the law; are innovative and proactive in thought and in 
action; and support, encourage and provide opportunities for individual growth."

In Sekele v Orion Money Purchase Pension Fund \& Another [2001] 6 BPLR 2148 (PFA). The Adjudicator set out the modus operandi of this office in the following words:

"[T]he purpose of this office is not only to determine and dispose of complaints lodged in terms of section 30A(3) but also to investigate complaints.... Where our investigation reveals any form of maladministration or unlawfulness, which has not been pleaded by the parties, it will nevertheless be further investigated and forms part of the ruling where necessary. Whenever our investigation reveals a related issue not initially raised or accurately formulated by the parties, all interested persons shall be afforded an opportunity to submit further submissions and evidence in respect of this new issue."

\subsection{The inception of the OPFA}

The OPFA was incepted with effect from the 19 April 1996 pursuant to recommendations made by the Mouton Committee of Investigations into a Retirement Provision System for South Africa. The OPFA has been in existence for nearly fourteen years but only appointed the first Pension Funds Adjudicator in January 1998.

The insertion of the new chapter VA has been borrowed liberally from the provisions establishing the office of the Pension Ombudsman in the United Kingdom. In many respects the two offices function similarly and perform the same tasks. In other respects, mainly because of significant differences in legal systems, political history and culture, the experience of the two offices are quite different (Murphy, 2001).

The office receives thousands of complaints annually. According to the PFA (2012:2), about 5368 complaints were received during 2011 and 2012 by the OPFA and 5306 were accordingly resolved.

This ranges from retirement fund, early retirement death benefit, ill health/disability benefit, withdrawal of benefits, spouse/dependent benefits, section 14 transfer value surplus enhancements and divorce benefit. It is of paramount importance that the OPFA remains impartial when adjudicating these matters that are within its area of jurisdiction.

The response to the question as to how the OPFA can be impartial for example is that considerations can be made to the remarks passed in Findlay v The United Kingdom (Findlay) (1997) 24 EHRR 221 which provides some form of guidance to any tribunal, according it was stated that "As to the question of impartiality, the court, in the case of Findlay said that there are two aspects to this requirement. First, the tribunal must be free of personal prejudice or bias. Secondly it must be impartial from an objective viewpoint, that is, it must offer sufficient guarantees to exclude any legitimate doubt in that respect."

\subsection{Appointment and powers of the Pension Funds Adjudicator}

The court observed in Finlay's case that in order to establish whether a tribunal can be considered as independent regard must be inter alia to the manner of appointment of its members and their term of office, the existence of guarantees against outside pressures and the question of whether the body presents an appearance of independence.

Against the above background, the Minister of Finance is responsible for the appointment of the Adjudicator based on Section $30 \mathrm{C}(2)$ of the Act which reads: No person shall be appointed as Adjudicator, Deputy Adjudicator or Acting Adjudicator unless he or she is qualified to be admitted to practise as an advocate under the Admission of Advocates Act No. 67 of 1964, or as an attorney under the Attorneys Act No. 53 of 1979, and-

a. for an uninterrupted period of at least 10 years practised as an advocate or an attorney; or

b. for an uninterrupted period of at least 10 years was involved in the tuition of law and also practised as an advocate or attorney for such period as renders him or her suitable for appointment as Adjudicator; or

c. possesses such other experience as renders him or her suitable for appointment as Adjudicator, Deputy Adjudicator or Acting Adjudicator. It is however required in terms of Section $30 \mathrm{C}(1)$ of the Act that before the Minister makes such an appointment, the Minister consults with the Financial Services Board (FSB).

Section $30 \mathrm{C}(3)$ of the Act stipulates that the appointment of the Adjudicator and Deputy Adjudicator shall be for a period of no more than three years and both the latter and the former may be re-appointed on expiry of such term of office. According to Section $30 \mathrm{C}(5)$ of the Act, the Minister may however remove the Adjudicator or Deputy Adjudicator from office on the grounds of misbehaviour, incapacity or incompetence. This may also be done after the Minister consults with the FSB.

In the event that the Adjudicator resigns, is removed or his or her term of office expires, the Minister may appoint an Acting Adjudicator to act as Adjudicator until a competent person is appointed in terms of Section $30 \mathrm{C}(4)$ of the Act. 
Section 30C (6) of the Act provides that an Acting Adjudicator has all the powers of the Adjudicator and must perform all the duties of the Adjudicator as contemplated in section 30Q.

The Act outlines the powers of the Adjudicator in terms of section 30Q, and this includes amongst others doing everything necessary or expedient for the achievement of his or her objects and the performance of his or her functions. The Adjudicator has the same powers as a High Court judge but only in respect of matters over which he or she has jurisdictions. (George and Hanekom, 2007).

The Adjudicator is entitled to make appropriate orders including: declaratory orders, prohibitory interdicts, orders for the payment of money and specific performance. However unlike the High Court, OPFA is not a creature of statute, thus the Adjudicator has no inherent jurisdiction. In Meyer v Iscor Pension Fund [2003] 3 BPLR 4427 (SCA), The court said that "At the risk of stating the obvious, it must be borne in mind that, since the office of the Adjudicator is not a creature of statute; the Adjudicator has no inherent jurisdiction. His powers and functions are confined to those conferred upon him by the provisions of Chapter VA."

\subsection{The jurisdiction of the Pension Funds Adjudicator}

The knowledge of jurisdiction of any forum is vital as it assists lay persons to appropriately choose the correct forum to lodge a complaint. Because the membership of a retirement fund is often an employment benefit, certain disputes may appear to fall within the jurisdiction of the Pension Funds Adjudicator and the Commission, Mediation and Arbitration (CCMA). It therefore becomes imperative to understand the difference between these forums so that disputes are referred to the correct body (George and Hanekom, 2007).

The CCMA considers all unfair practices and procedures in relation to retirement funds to the extent that they constitute "unfair labour practices" (such as the unfair conduct of an employer in relation to the provision of retirement benefits). Accordingly, the CCMA has been reluctant to hear disputes in respect of retirementfunds (George and Hanekom 2007). The court observed in the case of Group of Concerned SAPREF Pensioners v SAPREF Pension Fund and Others [2000] 1 BPLR 44 (PFA) that it is therefore prudent that complainants with disputes of interest refer such a dispute to the OPFA.

The Adjudicator only has jurisdiction to determine disputes that fall within the definition of a complaint. However, the Adjudicator does not have jurisdiction over the following:

Funds to which the State contributes, provided they are not registered in terms of the Act; for example Government Employees Pension Fund (GEPF) as decided in the case of Government Employees Pension Fund, Transnet Pension Fund and South African Post Office Retirement Fund. If a person who works for the government has a complaint about a government pension, that complaint should be sent to the Public Protector (Sigwadi, 2004). However, the ruling by the Pension Funds Adjudicator in Eastman v Temporary Employees Pension Fund v University of Cape Town (1999) 1 Jutas Pension LB 153 (WC) confirmed that the Adjudicator's jurisdiction is not automatically excluded in respect of government pension funds. Members of retirement funds to which the State contributes financially may properly lodge complaints with the Adjudicator if the retirement fund has been registered under section $4 \mathrm{~A}(2)$ of the Act.

There are some funds that are in the head offices of the participating employers outside South Africa but have branches in South Africa. However, in terms of section 4(a) of the Act, the Registrar may permit these funds to register under the Act if:

- the Registrar is satisfied that the rules of the fund applicable to members resident in the Republic are not less favourable than those applicable to members resident outside the Republic, taking into consideration differences in the conditions of service;

- the registrar is satisfied that adequate arrangements exist for ensuring the financial soundness of the fund; and

- In terms of Section 2 of the Act, the fund furnishes such security as the registrar may from time to time require for the payment of any benefits which may become payable to members resident in the Republic who are South African citizens, or otherwise satisfies the registrar that it will be able to pay such benefits in terms of Section 2 of the Act.

- According to Section $30 \mathrm{H}(2)$ of the Act., complaints in respect of which proceedings have already been instituted in a civil court, if the subject matter is the same. In Stow v First Bowring Staff Pension Fund and Another (2003) 9 BPLR 5157 (PFA), the Adjudicator observed that he lacked jurisdiction in that the complainant had already issued summons in the High Court. In the case of Dakin v Southern Sun Retirement Fund (1999) 9 BPLR 22 (PFA), the Adjudicator had held that the CCMA was not a civil Court and therefore the 
proceedings in the CCMA were accordingly not proceedings in a civil Court for the purposes of section $30 \mathrm{H}(2)$.

- In terms of Section $30 \mathrm{H}(4)$ of the Act, complaints in connection with a scheme for the apportionment of surplus in terms of section 15B which relate to the decisions taken by the board, or any stakeholder in the fund, or any specialist tribunal convened in terms of section $15 \mathrm{~K}$. Section $30 \mathrm{H}(4)$ was added to specifically exclude the Adjudicator's jurisdiction over complaints relating to the apportionment of surplus in terms of section 15B (George and Hanekom, 2007).

- Complaints where the fund is under liquidation. Section 28 of the Act provides for members and creditors of the fund to lay their claims with the liquidator where the fund is under liquidation as decided by the court in the case of Groenewald v SaskoRetirementb Fund and Another [2003] 7 BPLR 4905 (PFA). In Bailao v Du Plessis, Smit and Co and Another (2000) 11 BPLR 1193 (PFA), the Adjudicator held that section 28 of the Act did not allow him to investigate a complaint relating to the distribution of assets upon the dissolution of a pension fund.

- Complaints relating to the money invested in a trust. The Adjudicator has pronounced in Niewenhuizen v SAB Staff Provident Fund and Another 2000] 12 BPLR 1413 (PFA) at paragraphs 24 and 25 that the OPFA has no jurisdiction over trust funds and that where a breach of trust is alleged in a trust fund, the matter falls to be determined by the ordinary courts. Put differently, if your complaint relates to the decision of the fund to place the benefit in a trust arrangement, then such a decision can be reviewed by the Adjudicator.

One of the challenges facing the OPFA is the receipt of a substantial number of frivolous new complaints, where the OPFA lacks jurisdiction. It therefore shows a dire need to have members of the fund educated on what constitutes a 'complaint' in terms of the Act which will confer the OPFA with jurisdiction to expeditiously resolve the disputes. We opine that this measure would reduce the frivolous new complaints which create an unnecessary back-log that prevents the OPFA's object to dispose complaints in an economical and expeditious manner.

In the case of IBM South Africa Pension Fund v IBM South Africa (Pty) Ltd (2000) 21 ILJ 1467) (PFA), the Counsel for the respondent contended that a pension fund (IBM South Africa Pension Fund) cannot be a complainant in respect of a complaint concerning the interpretation of its own rules. For this proposition they relied on the definition of "complaint" and on section 30G of the Act. The court decided in the IBM's case that since the Adjudicator only has jurisdiction to consider a complaint made by a complainants defined, they argued, jurisdiction is absent in this case. It therefore becomes necessary to determine what a complaint is and who can lodge a complaint.

Section $30 \mathrm{G}$ deals with parties to a complaint. It provides that:

"The parties to a complaint shall be -

a) The complainant;

b) The fund or person against whom the complaint is directed;

c) Any person who has applied to the Adjudicator to be made a party and who has a sufficient interest in the matter to be made a party to the complaint;

d) Any other person whom the Adjudicator believes has a sufficient interest in the matter to be made a party to the complaint."

From the definition we agree with the Adjudicator that there is no reason why the complainant should not be the fund and the respondent the person against whom the complaint is directed. The definition of "complainant" includes "a board of a fund or member thereof". According to the court in the IBM case:

"Counsel for the respondent advanced no reason why the trustees of the complainant fund should not be complainant as defined. Instead they rely on the definition of "complaint" (in addition to section 30G of the Act) for the proposition that the pension fund cannot be a complainant in respect of a complaint concerning the interpretation of its own rules. It is an argument that, I confess, I have difficulty comprehending... in my view, this complaint falls squarely within the ambit of paragraph (d) of the definition of "complaint".

The Courts often warns that giving a strict and literal meaning of the definition of complaint would offend against the very purpose of the Act. The court in Hoffmann v Pension Funds Adjudicator and others [2012] 2 All SA 198 (WCC) stated that should a complaint allege that a dispute of fact or law has risen in relation to the fund between the employer and employee, and that such a dispute has a bearing on the pension benefits payable to the member of such a fund, then such complaint would indeed qualify as a "complaint" (sub paragraph (c) of the definition) for the purposes of the Act.

If the dispute is to be resolved in the employer/employee matter is also relevant to the pension dispute, as the OPFA would have jurisdiction to determine the dispute. It is therefore a broader and more measured interpretation of "complaint" as opposed to a narrow interpretation that would lead to fair, just and equitable results which the Act intends to achieve. 
The court in the Hoffmann case made reference to Central Retirement Annuity Fund v Adjudication of Pension Fund and Another, where the court warned against a too formalistic approach in dealing with complaints procedure in terms of the Act.

It was also observed in Hoffmann's case that if the dispute is such that the pension related matter cannot be resolved without the employer/employee dispute being resolved first then the OPFA is not the appropriate forum to hear the matter. However, it should not be a general rule that the employer/employee dispute should first be resolved at all cost at another forum before any attention is given to a genuine pension related complaint. Where a pension related complaint exists simultaneously or parallel with an employer/employee related dispute, the pension related dispute, if at all possible, should be resolved by the OPFA without having to deal with the employer/ employee related dispute.

\section{The Procedure to Lodge a Complaint with the OPFA}

Section 30A of the Act outlines the procedures which the must be adhered to in order to lodge a complaint. Accordingly to section $30 \mathrm{~A}(1)$ of the Act, the complainant has to lodge a written complaint to the fund. Thereafter the board of the fund has to consider the complaint and, the board of the fund or the employer must respond in writing to the complainant within 30 days from date of receipt of the complaint in terms of section $30 \mathrm{~A}(2)$ of the Act. If the fund or the employer who participates in the fund does not respond within the 30 days period or the complainant is not satisfied with the response, the complainant may lodge a complaint in writing with the OPFA.

According to Nevondwe et al. (2013) the complainant may submit his or her complaint in any language and the OPFA will, if necessary, obtain a translation of such communication. The office's documentation on how to submit a complaint has also been translated into various languages commonly used in South Africa. Personal and telephonic contact is usually conducted in the complainant's preferred language. The OPFA has also placed the procedures on how to lodge the complaint on the website (Nevondwe et al. 2013).

An understanding of this procedure is vital for the effective resolution of disputes. It would seem that a significant number of complainants approach the OPFA without first submitting their complaints to their funds administrators or employers (PFA 2011/12). According to Sigwadi (2004), a direct application to the Adjudicator for relief without first lodging a written complaint with the fund or participating employer or administrator is unscrupulous in law as it is lack of compliance with the Act. Instead of investigating the complaint, the Adjudicator may send it back for failure to comply with the Act. If the Adjudicator intends to investigate a complaint, then under section 30F he or she must allow the fund or person against whom the allegations contained in the complaint are made the opportunity of commenting on the allegations.

This approach by complainants requires closer inspection by all role players. Funds, administrators and employers need to educate members/beneficiaries of the provisions of section 30A of the Act (Sigwadi, 2004). If this procedure is followed, the Adjudicator will then acquire jurisdiction in terms section $30(A)(3)$ of the Act to determine the dispute in terms of Chapter VA of the Act.

A complaint lodged with the Adjudicator should contain the following information:

Full personal details, including all contact details

Full details of the employer/fund/respondent, including all contact details

History of employment and membership of the fund

Full specifics of the complaint, with particular reference to the definition of a complaint, contained in section 1 of the Act

Proof that the respondent had been approached prior to the submission to the Adjudicator (this could either be a copy of the letter, a fax confirmation sheet or a copy of proof of registration of the document)

A copy of the respondent's response, if available

All relevant (and only relevant) documents in support of the allegations/dispute

Details of the remedy sought (PFA, 2013).

The question which perhaps needs to be determined is for what purposes does the section $30 \mathrm{~A}$ procedure serve? Is there a need to continue to utilize this procedure? We opine that the section $30 \mathrm{~A}$ procedure remains a relevant tool in realizing the objectives of the OPFA to dispose complaints in a procedurally fair, economical and expeditious manner. This procedure remains relevant in that it complies with the rules of natural justice (the audi alteram partem rule). The court has prescribed in the case of Euijen v Nedcor Pension Fund [2000] 5 BPLR 465 (PFA) that it is therefore evident that section $30 \mathrm{~A}$ procedure fulfils the following purposes:

- It gives the fund or the employer an opportunity to deal with the complaint without first having to justify its 
conduct before the Adjudicator.

- It prompts the fund or the employer to formulate a reply narrowing the issues in dispute, it establishes an alternative and an informal set of pleadings; and

- it will, one hopes, prompt the industry to establish internal complaints procedures and mechanisms of compliance. Thus it is essential that complainants comply with its terms.

\subsection{Time limits on lodging complaints to the OPFA.}

The Act limits the period of time within which a complaint can be submitted to the OPFA. It therefore becomes necessary for the complainant to familiarise himself or herself with the time limits for submitting such a complaint to the OPFA. The time limits on lodging complaints to the OPFA are regulated by section $30 \mathrm{l}$ of the Act.

Prior to its amendment, section 30l, which was introduced in 1996 by the Pension Funds Amendment Act 22 of 1996 provided that the Adjudicator could not investigate a complaint if the act or omission to which it related had occurred more than three years before the date on which the complaint was received by him/her in writing (Nevondwe, 2008). Prior to its amendment, section 301 read as follows:

"(1) The Adjudicator shall not investigate a complaint if the act or omission to which it relates occurred more than three years before the date on which the complaint is received by him or her in writing.

If the complainant was unaware of the act or omission contemplated in subsection (1), the period of three years shall commence on the date on which the complainant became aware or ought reasonably to have become aware of such occurrence, whichever occurs first.

The Adjudicator may on good cause shown or of his or her own motion -

(a) either before or after the expiry of any period prescribed by this Chapter, extend such period; [or]

Condone noncompliance with any time limits prescribed by this Chapter."

The legislature had good intentions when enacting the above provisions. The provisions afford the complainants the opportunity to have their complaints considered although the three year period had lapsed. It is however required that the complainant show that there is a good cause for not lodging the complaint within the prescribed periods. Should the Adjudicator be satisfied that good cause has been shown, the Adjudicator will be able to consider an extension. The unawareness of the spectre of prescription and its adverse impact on the prosecution of his claim is one of the good causes which may be shown in order for the Adjudicator to consider the extension. Section 30l (1) of the Act is a timebarring, not a prescriptive provision (Sigwadi, 2004).

Majority of the poor are not privy to this time-barring provision, although the Act provides for an extension of the three year period, the question that remains is whether there is a need to have this time barring provision from the onset. It has been submitted that there is a good reason for a limit to be imposed on the time during which litigation may be launched and the Constitutional Court has pronounced on this issue. The court explained in Mohlomi v Minister of Defence 1997 (1) SA 124 (CC) in paragraph [11 thus:

"Rules that limit the time within which litigation may be launched are common in our legal system as well as many others. Inordinate delays in litigation damages the interest of justice. They protract the disputes over the rights and obligations that are sought to be enforced, prolonging the uncertainty of all concerned about their affairs. It is not always possible to adjudicate satisfactorily on cases that have gone stale in the long run. By then witnesses may no longer be available to testify. The memories of those whose testimonies should be obtained have faded and become unreliable. Documentary evidences may have disappeared. Such rules prevent procrastination and harmful consequences that may result from delays. They serve a purpose to which no exception in principle can cogently be taken."

Similarly, it was held in Vandeyar v UTICO Staff Pension Fund [2000] 3 BPLR 332 (PFA) that the purpose of section 30I (1) of the Act is to ensure finality and certainty in pension fund affairs and to promote efficiency by an incentive for the prompt enforcement of complaints: "all legal systems accept that the operation of obligations should be limited by requiring enforcement within a reasonable period of time".

In Melane v Santam Insurance Company Limited 1962 (4) SA 531 (A), the Appeal Court pronounced on the standard that had to be met in order for condonation to be granted. Holmes JA held (at 532):

"In deciding whether sufficient cause has been shown, the basic principle is that the Court has discretion, to be exercised judicially upon a consideration of all facts, and in essence it is a matter of fairness to both sides. Among the facts usually relevant is the degree of lateness, the explanation therefor, the prospects of success, and the importance of the case. Ordinarily these facts are interrelated: they are not individually decisive, for that would be a piecemeal approach incompatible with a true discretion, except if there are no prospects of success, then there would be no point in granting 
condonation. Any attempt to formulate a rule of thumb would only serve to harden the arteries of what should be a flexible discretion. What is needed is an objective conspectus of all the facts. Thus a slight delay and a good explanation may help to compensate for prospects of success which are not strong. The importance of the issue and strong prospects of success may tend to compensate for a long delay and the respondent's interest in finality must not be overlooked."

In the present circumstances, the existence of good cause was determined according to various considerations (Nevondwe, 2008) such as the following:

- the degree of lateness and the reasons for it;

- the importance of the case;

- the complainant's prospect of success on the merits;

- the possibility of harm to either party; and

- any genuine attempts at settling the dispute.

However, this position applies to cases which have been lodged to the OPFA before 13 September, 2007. Section 301 of the Pension Funds Amendment Act imposes certain time limits with regard to lodgement of complaints before the Adjudicator and states as follows:

"(1) The Adjudicator shall not investigate a complaint if the act or omission to which it relates occurred more than three years before the date on which the complaint is received by him or her in writing.

(2) The provisions of the Prescription Act, 1969 (Act No. 68 of 1969), relating to a debt apply in respect of the calculation of the three year period referred to in subsection (1)."

Parliament has thus removed the Adjudicator's discretion by abolishing section 301(3), and has linked section 30I to the provisions of the Prescription Act concerning a debt; accordingly if the complaint has been lodged outside the three year period, it cannot be investigated by the Adjudicator (Nevondwe, 2008). Section 30l of the Act place poor people in the rural areas at a disadvantage because majority of these people are not aware of their pension law rights. This means that even though they are entitled to the pension or provident funds they cannot access their benefits due to unawareness of the time limit if they lodged their complaint outside the three year period (Nevondwe, 2008).

Section $30 \mathrm{l}$ creates a serious dilemma especially with the distribution of death benefits in terms of section $37 \mathrm{C}$ of the Act. The implications of section 30l on the distribution of death benefits are that those dependants who lodged their complaints outside the three-year period would not be able to access the benefits, which then is contrary to the object of section 37C to protect dependency (Matotoka, 2013). Section 11 of the Prescription Act 68 of 1969 stipulates that "the period of prescription of debt shall be three years in respect of any other debt not mentioned in subsection (a), (b) and (c).

The previous provision in the Act was better since it gave the Adjudicator the discretion to condone noncompliance within the three year period if there is a prospect of success on the complainant (Nevondwe, 2008).

\subsection{Legal representation}

A right to legal representation is today, generally regarded as a necessity, and not as a privilege (Buchner, 2013). Due to the complex structure of pension arrangements in South Africa, it would seem unreasonable to deny parties before the Adjudicator legal representation. However legal representation is not permitted before the Adjudicator in terms of section $30 \mathrm{~K}$ of the Act. The aim of this provision is to ensure that proceedings before the Adjudicator are informal, accessible, expeditious and inexpensive. It also prevents prejudice to an individual member with a small income who faces opposition from large pension funds that can afford expensive legal representation (Sigwadi, 2004).

The investigative process is therefore modelled more closely on the European "inquisitorial" manner than the South African adversarial procedure, although it has features of both. Despite the introduction of a process which is inexpensive and expeditious, there are often demands from lawyers within the industry to adjudicate some complaints using more traditional adversarial methods (Murphy, 2001). Many concede that the investigative approach relying on written advocacy has had considerable success in run of the mill complaints relating to benefit entitlements. Complex matters arising out of restructuring schemes, it is argued, are apt to necessitate more conventional forms (Murphy, 2001). The prohibition of legal representation raises alarms especially where huge sums involved in pension disputes (Sigwadi, 2004).

\section{The Interplay of Conciliation and Arbitration in the CCMA and OPFA}

The CCMA is well known for the Alternative Dispute Resolution (ADR) mechanisms that are used to resolve matters expeditiously. According to the South African Law Reform, ADR provides an opportunity to resolve disputes and conflict 
through the utilisation of a process that is best suited to the particular dispute or conflict (Stipanowich, 2004). Some of these mechanisms include the Conciliation and arbitration.

Conciliation hearing is a process where a third party meets with the parties in a dispute and explores ways to settle the dispute by agreement. Conciliation provides for quick and fair resolution of disputes. The conciliation process is uncomplicated, inexpensive and does not require any legal representation. The decision to settle is in the hands of the parties involved. Contrary to conciliation, arbitration is a more formal process in that it does not promote the continuation of negotiations to find an amicable solution (Fenn, 2008). During arbitration proceedings the arbitrator listens and investigates the demands and counters demands of both parties and decides on a final settlement in a form an arbitration award (Abrams, 1977). The award is then imposed on the parties after hearing the evidence. This is legally binding on both parties.

In Parekh v Shah Jehan Cinemas (Pty) Ltd and Others 1980 (1) SA 302. Didcott J said:

\begin{abstract}
Arbitration is a method for resolving disputes (Posner, 1986). That alone is its object, and its justification. A disputed claim is sent to arbitration so that the dispute which it involves may be determined. No purpose can be served, on the other hand, by arbitration on an undisputed claim. There is then nothing for the arbitrator to decide. He is not needed, for instance, for a judgment by consent or default (Zack, 1984).
\end{abstract}

Should arbitration be made compulsory in the OPFA? The consequence of arbitration proceedings is that the decision of the arbitrator would be final and binding. We are of the view that this would not advance the interest of the parties. Pension law is a complex field and to have a decision of one tribunal as final and binding would be prejudicial. The current system, should be retained because the adjudicator's decision is not final. Any party who feels aggrieved by the determination of the adjudicator may appeal to the High Court for relief. The High Court may consider the merits of the complaints and may make any order it deems fit. The High court decision is appealable, subject to leave, to the full bench or Supreme Court of appeal, and if a constitutional issue is involved, it can go all the way to the Constitutional Court (Myburgh, 2010).

The first striking feature of the Pension Funds Act is that the adjudicator is empowered to resolve a complaint in only one way, and that is by making a determination. There is no obligation on the adjudicator to resort to other wellrecognised means of resolving a complaint by using ADR, such as conciliation, facilitation or making a recommendation. The Adjudicator is merely vested with discretion to refer a complaint for resolution by conciliation (Myburgh, 2010).

Conciliation in the OPFA has proven to be a success in resolving disputes. According to the Annual Report of the OPFA, conciliation continues to be of great assistance in resolving complaints. In the period 2012-2013, 630 complaints were finalised, mostly through settlements. The conciliation service proved to be invaluable, especially in finalising complex matters lodged over three years ago with the OPFA. Compared to the 2011 - 2012 financial year, the New Complaints Unit resolved 22\% more complaints, whilst the Conciliation Unit resolved 52\% more complaints and the Adjudication Unit finalised 93\% more complaints through determinations.

\title{
6. Conclusions and Recommendations
}

The performance of OPFA in resolving disputes so far should be commended. It is evident that the OPFA is committed to resolving complaints in a procedurally fair, economical and expeditious manner. However, more still needs to be done especially to reduce delays in the processing of complaints, increasing the accessibility to and awareness of members of pensions fund about the services of the OPFA (PFA, 2011/12).

The role of the OPFA is critical in protecting members of the retirement funds. However an alarming concern relates to the fact that currently the Adjudicator has jurisdiction only in funds which are registered with the Registrar of Pension Funds in terms of the PFA (Nevondwe, 2010). The Adjudicator lacks jurisdiction on the GEPF which has more than 1, 16 million contributing members and 311345 pensioners and beneficiaries, the Transnet Pension Fund and South Africa Post Office Retirement Fund (Nevondwe, 2010). This creates a concern since members of the above fund do not have recourse as they have to contact the fund directly if they are not satisfied with the benefits they have received.

In a recent development, a disturbing phenomenon pervading the OPFA is that almost $60 \%$ of the total complaints were against the Private Security Sector Provident Fund (PSSPF) regarding arrear contributions, none or late payments of withdrawal benefits, payments of death benefits and provision of benefit statements. Whilst the number of complaints against the PSSPF had decreased to a third by 31 March, 2013.The situation is untenable as the PSSPF's noncompliance with various aspects of the Pension Funds Act is overly engaging the OPFA, to the prejudice of the pension funds industry as a whole, its members who pay levies and beneficiaries (PFA, 2011/12). 
The lack of co-operation and trust between pension fund members and beneficiaries on the one hand, and administrators, pension funds and boards of trustees on the other hand is of great concern. In the reporting period, 4127 determinations were handed down, of which in 2399 cases, relief were granted to the complainant. This clearly points to the need for fund trustees and administrators to work harder at communicating and educating members and beneficiaries about fund rules and benefits (PFA, 2011/12).

The initiative to subject trustees to a robust training would play a significant role in the adjudication of complaints. This means that there would be better compliance with governing legislations which in essence would reduce unnecessary backlog of complaints.

Over and above, majority of South Africans are now able to have their complaints considered and adjudicated without delay. The OPFA permits the usage of language understandable by laymen unlike litigation where strict procedures need to be adhered to. In many instances, complainants do not have enough money to have their disputes resolves by courts.. It is on this basis that the inception of the OPFA is welcomed; more especially as it does not discriminate against income earners. Put differently, the OPFA would consider any complaint provided that such a complaint is defined in terms of the Act. Financial status is not a consideration on whose complaints will be s considered by the OPFA.

\section{References}

Abrams RI 1977. The integrity of the arbitral process, Michigan Law Review, 79(2):231-264.

Adler M 2006. Tribunal Reform: Proportionate Dispute Resolution and the Pursuit of Administrative Justice, The Modern Law Review, 69(6): 958-985.

Buchner JJ 2003. The constitutional right to legal representation during disciplinary hearings and proceedings before the CCMA. From (Retrieved May 17, 2012).

Colby BG 1998. Negotiated Transactions as Conflict Resolution Mechanisms: Water Bargaining in the U.S. West, Natural Resource Management and Policy, 15:77-94.

Fraser B 2001. The mediator as power broker, John Benjamins BV Pujblishers, Amstredam, The Neitherlands.

Fenn, 2008. Commercial Management of Projects. Defining a discipline? In: (Lowe D, Leiringer R, Eds). Conflict management and dispute resolution, Blackwell, publishing Ltd, Oxford, UK.

George L M, Hanekom K 2007. The manual on South African Retirement Funds and other employee benefits, Lexix, Nexis, Durban, South Africa.

George L Marx, and Hanekom K 2010. The Manual on South African Retirement Funds and other Employee Benefits, Lexis Nexis, Durban, South Africa.

Hanekom 2007. Retirement Planning Manual on South African Retirement Funds and other Employee Benefits,

Hanekom K, Marx GL 2005. The manual on South African retirement funds and other employee benefits,Durban: Lexis Nexis, South Africa.

Kwakwala BOK 2010. A critical evaluation of the dispute resolution function of the Commission for Conciliation, Mediation and Arbitration (CCMA).

http://scholar.google.com/scholar?q=A+critical+evaluation+of+the+dispute+resolution+function+of+the+Commission+for+Concilia tion\%2C+Mediation+and+Arbitration+\%28CCMA\&btnG=\&hl=en\&as_sdt=0\%2C5. (Retrieved September 11, 2013).

Lew JDM, Mistelis LA 2003. Comparative international commercial arbitration, Kluwer Law International, Amstredam, Neitherlands.

Matotoka MD, Section 37C of the Pension Funds Act, 24 of 1956: A social security measure to escape destitution. LLM dissertation, University of Limpopo, 2013. (Unpublished).

Merwe T 2004. The occupational pillar of the South African pension system, Development Southern Africa, 21(2): 303-327.

Murphy J 2001. Alternative Dispute Resolution in the South African Pension Funds Industry: an Ombudsman or a Tribunal?, a speech to the IPEBLA Conference in Bordeaux.

Murphy J 2001. Alternative Dispute Resolution in the South African Pension Funds Industry: an Ombudsman or a Tribunal? a speech to the IPEBLA Conference in Bordeaux.

Nevondwe $L$ 2008. Time limits on lodging complaints to the Pension Funds Adjudicator, Juta'sBusiness Law, 16:2-13.

Nevondwe $L$ 2009. The law regarding the division of the retirement savings of a retirement fund member on his or her divorce with specific reference to Cockcroft v Mine Employees' Pension Fund, [2007] 3 BPLR 296 (PFA), Law, Democracy and Development Journal, 13(1):12-9.

Nevondwe L 2010. South African Social Security and Retirement Reform: A long journey towards the redrafting of the new Pension Funds Act, Pensions an International Journal, 15(4): 6-18.

Nevondwe L 2010. South African Social Security and Retirement Reform: A long journey towards the redrafting of the new Pension Funds Act, Pensions an International Journal, 15:287-296.

Nevondwe L, Odeku K and Matotoka M 2013. The Governance Of Retirement Funds in Members Rights and Trustees duties in South Africa: A lesson learnt from USA, UK and Malawi ,East Asian Journal of Business Economics, 1(3):55-70.

Nevondwe L, Odeku OK, Matotoka M 2013. The Governance Of Retirement Funds in Members Rights and Trustees duties in South 
Africa: A lesson learnt from USA, UK and Malawi , East Asian Journal of Business Economics, 1(3):55-70.

PFA 2011/2012. Pesion Funds Adjudicator Annual report 2011/12. From www.pfa.org.za. (Retrieved June 29, 2013).

PFA 2013. Pesion Funds Adjudicator, How to lodge a complaint. From www.pfa.org.za. (Retrieved January 22, 2013).

Sigwadi M 2004. Dispute resolution and the Pensions Funds Adjudicator, Juta'sBusiness Law, 12: 2-14.

Posner RA 1986. The summary jury trial and other methods of alternative dispute resolution: Some cautionary observations, The University of Chicago Law Review, 53(2): 366-393.

Sigwadi S 2004. Dispute resolution and the Pensions Funds Adjudicator, Juta Business Law Journal, 12(2):3-12.

Stipanowich TJ 2004. ADR and the "Vanishing Trial": The Growth and Impact of "Alternative Dispute Resolution, Journal of Empirical Legal Studies, 1(3):843-912.

Zack A 1984. Arbitration in practice, Cornell University Press, USA. 
